\title{
22: 40851379-40847001
}

National Cancer Institute

\section{Source}

National Cancer Institute. 22:40851379-40847001. NCI Thesaurus. Code C42109.

Physical location of CYP2D6_Gene 